Socialist Studies: the Journal of the Society for Socialist Studies 5(2) Fall 2009: 90-112

Copyright (C) 2009 The Author(s)

SPECIAL SECTION ON RETHINKING LENINISM

\title{
Lenin's Aggressive Unoriginality, 1914-1916
}

\author{
LARS T. LIH \\ Montréal, Québec
}

\begin{abstract}
:
Lenin received a severe shock in 1914 when the main parties of the socialist Second International supported the war effort of their respective governments. But the shock did not lead to his rejection of the prewar Marxist orthodoxy but rather to an outraged affirmation of this orthodoxy against those who (in Lenin's view) had betrayed it. Lenin's rhetorical stance can therefore be described as 'aggressive unoriginality'. Lenin insisted that the key themes of 'Left Zimmerwald' - the name given to the socialist current of which he was the principal spokesman from 1914 to 1916-were based squarely on the prewar consensus of 'revolutionary Marxists', particularly as expressed by Karl Kautsky. Among these themes are the underlying idea of a revolutionary situation, the assumption that the war had created a revolutionary situation, and the claim that 'socialist patriotism' during the war represented the triumph of prewar opportunism.

\section{Résumé:}

Lénine a reçu un choc sévère en 1914 quand les principaux partis de la Deuxième Internationale socialiste ont soutenu l'effort de guerre de leurs gouvernements respectifs. Toutefois, le choc ne l'a pas amené à rejeter l'orthodoxie marxiste de l'avant-guerre mais plutôt à affirmer outrageusement cette orthodoxie contre ceux qui, de son point de vue, l'avaient trahie. La posture rhétorique de Lénine peut ainsi être décrite comme 'banalement agressive.' Lénine soutenait que les thèmes clés de la 'Gauche de Zimmerwald' - le nom donné au courant socialiste dont il était le principal porte-parole entre 1914 et 1916 - étaient fondamentalement basés sur le consensus d'avant-guerre des 'Marxistes révolutionnaires,' comme pouvait l'exprimer en particulier Karl Kautsky. Parmi ces thèmes figurent l'idée sous-jacente d'une situation
\end{abstract}

Lars T. Lih was born in Richland, Washington (USA). After getting his education here and there (including two years in the UK and one year in the USSR) and working here and there (including six years in Washington, DC), he is now a Canadian citizen and an unaffiliated scholar living in Montréal, Québec. His books include Bread and Authority in Russia, 1914-1921 (1990), Stalin's Letters to Molotov (1995), and Lenin Rediscovered (2006). He has also written a fair number of articles about Russian and Soviet history. He can be contacted at larslih@yahoo.ca.

Lars T. Lih est né à Richland, Washington (Etats-Unis). Après avoir étudié ici et là, y compris deux ans en Grande Bretagne et une année en Union soviétique, et après avoir travaillé ici et là, y compris six ans à Washington, D.C., il est maintenant citoyen canadien et universitaire indépendant vivant à Montréal, Québec. Parmi ses livres sont (en anglais) Bread and Authority in Russia, 1914-1921 (1990), Stalin's Letters to Molotov (1995), et Lenin Rediscovered (2006). Il a également écrit plusieurs articles sur la Russie et l'histoire soviétique. II peut être contacté à larslih@yahoo.ca.

www.socialiststudies.com ISSN 1918-2821 
révolutionnaire, l'hypothèse que cette situation révolutionnaire a été créée par la guerre, et l'argument selon lequel le 'patriotisme socialiste' d'alors correspondait au triomphe de l'opportunisme de l'avant-guerre.

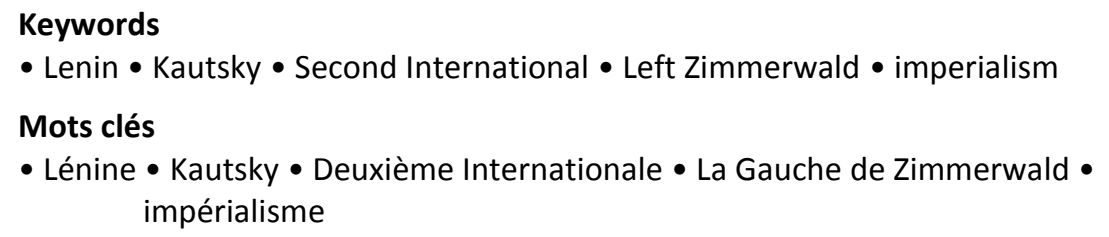

In the early summer of 1914, Lenin had very little idea of what the looming war would mean for him personally. He even assumed his work load would be eased somewhat if war actually broke out, since his connections with the Russian underground would be thoroughly disrupted. But when war finally came, it brought some devastating surprises. Even after Germany declared war on Russia on 1 August 1914, the Social Democratic parties in Germany, Austro-Hungary and France were still organizing mass protests against war. The main German Social Democratic Party (SPD) newspaper, Vorwärts, continued to thunder against the imperialist war and to threaten the capitalist warmongers with revolutionary action. But on 5 August Lenin received a major shock: the SPD Reichstag delegation had voted unanimously for war credits. Forgotten was the traditional cry of 'not one penny - not one man' for the capitalist state. When Lenin first saw the headlines in the village of Poronino (his summer residence outside Kraków), he was sure that it must be a provocation, a trick by the government to confuse the opposition.

Lenin soon had his own firsthand experience with war hysteria. The local officials in Austrian Poland suspected the outlandish Russian emigrant of espionage. A police official reported that many meetings of Russian nationals had taken place at the residence of V. Ulyanov. There were rumors that Ulyanov had been seen taking photographs in the surrounding hills, but these proved unfounded. Nevertheless, the police official was of the opinion that Ulyanov should be under lock and keyafter all, his identity papers were in French, he received money from Petersburg, and he was in a very good position to give information about Austria to the Russians.

Based on this irrefutable logic, Lenin was arrested and kept in the local jail from 8 August to 19 August. Thus the third decade of his political career began the same way as his first decade-in jail. But the big difference between 1894 and 1914 was that Lenin now had powerful 
friends on the outside. Among these was the leader of the Austrian Social Democrats, Victor Adler, who went to the Austrian Minister of the Interior to give personal assurance that no one was less likely to help the tsarist government than $\mathrm{V}$. Ulyanov. When the minister asked, 'are you sure he's an enemy of the tsar?' Adler answered, truly enough, 'he is a more implacable enemy than your Excellency.'

Orders soon came down to release Lenin, and even to allow him to travel to Switzerland. Right after getting out of jail, Lenin received another shock, in the form of a leaflet entitled 'Declaration of Russian Socialists Joining the French Army as Volunteers.' These Russian socialists outdid the Germans in their support of their government's war effort-they joined the ranks of an allied army. Among the émigrés in France who showed their devotion to internationalism in this way were several Bolsheviks.

Among many harrowing scenes, Lenin, his wife and his confused and soonto-die mother-in-law packed up and embarked on a week-long train trip to Bern, Switzerland (with a stop in Vienna to get necessary documents and to thank Victor Adler, soon to be a political enemy). When he arrived in Bern on 5 September, Lenin hit the ground running. The day he stepped off the train, he met with local Bolshevik émigrés and proposed a set of theses about the proper reaction to the war. Just a month had gone by since the outbreak of the war-a month mostly taken up with the hassles and uncertainties of jail and of picking up stakes - and yet Lenin was ready with theses that defined a radically new chapter of his career.

Yet Lenin had to endure one more shock-in some ways, perhaps the most disorienting of all. The betrayal of the SPD majority was an unpleasant surprise, but Lenin could instantly identify its cause: today's 'social chauvinists' (socialists who supported the war effort of their respective governments) were simply the incarnation of the age-old enemy: opportunism, 'the bourgeois nature and the danger of which have long been indicated by the finest representatives of the revolutionary proletariat of all countries' (Lenin 1960-68, 21:16). Anyone reading these words from Lenin's theses of September 1914 would have realized whom Lenin meant by 'the finest representatives': Rosa Luxemburg and Karl Kautsky. Luxemburg did in fact react to the war crisis as befitted an uncompromising foe of opportunism. But Kautsky? Lenin read with horror Kautsky's many articles from autumn 1914 in which Kautsky seemed to tie himself in knots, not exactly in order to defend the new opportunism, but to excuse it, to cut it as much slack as possible, to avoid burning bridges within the party. Could it be that Kautsky, Karl Kautsky, was an opportunist and a philistine? Lenin expressed his fury in letters: 'I hate 
and despise Kautsky now more than anyone, with his vile, dirty, selfsatisfied hypocrisy' (Lenin 1960-68, 35:167).

I have told the story of Lenin's experience in the opening weeks of World War I in such detail in order to bring a home a fact that needs to be explained, namely, that Lenin took almost no time at all to arrive at the basic positions that would guide his political activity until the outbreak of revolution in Russia in early 1917. The three most prominent themes in Lenin's wartime program are already evident. The first is the insistence on using the war crisis as an opportunity to foment socialist revolution in Europe. The second is the interpretation of the wartime split in the socialist movement in terms of the prewar framework of 'opportunism vs. orthodoxy'. This interpretation found practical form in the demand for a new socialist international that would be opportunist-free. Finally, Lenin becomes almost obsessive about a new form of opportunism that he calls kautskianstvo, named for its most emblematic representative, Karl Kautsky.

I believe that behind Lenin's unhesitating adaptation of his wartime platform is something I call his aggressive unoriginality. Lenin did not have to arrive at new ideas: he could work perfectly well with the ideas he had, ideas that he shared with most other orthodox Marxists (or at least so he claimed). 'Aggressive unoriginality' is a phrase that can be applied to Lenin's outlook and rhetoric from 1914 to about the middle of 1919. In this paper, I will restrict most of my comments to the pre-revolutionary period, 1914-1916, although I will also glance ahead at later developments. I mean three main things by the phrase 'aggressive unoriginality'.

\section{Lenin is not polemicizing with orthodox Second International Marxism.}

If you pick up and read Lenin's writings after 1914, you get the impression of a wholehearted rejection of the Second International and in particular of its main theoretical representative, Karl Kautsky. One reason for this misleading impression is Lenin's attacks on 'Kautskyism,' a term which most readers naturally understand to mean 'the system of ideas set forth in the writings of Karl Kautsky.' 'Kautskyism' is a somewhat misleading translation of kautskianstvo, which, as can be seen, is not an '-ism' word. And indeed, a careful examination of what Lenin means by this word shows that it does not mean Kautsky's prewar ideological outlook. Very much to the contrary: Kautsky's alleged repudiation of his prewar outlook - in deed, if not in words - is the archetypal manifestation of kautskianstvo. For Lenin, Kautsky is a renegade. 
Thus, for Lenin, Kautsky's behavior was emblematic of a general phenomenon which might be defined as 'talking the revolutionary talk but refusing to walk the revolutionary walk'. As such, many people who did not particularly agree with Kautsky on ideological issues were held by Lenin to be guilty of kautskianstvo-for example, Lev Trotsky and even non-Marxists such as Arthur Henderson.

After 1914, even as he violently attacked kautskianstvo, Lenin never tired of recalling the days when 'Kautsky was still a Marxist,' that is, up to about 1909. A detailed examination of these comments shows that they are almost all complimentary. Lenin explicitly endorses Kautsky's pre1909 writings on subjects as various as the coming era of war and revolution, opportunism, nationality policy, agricultural and peasant policy, and even dialectics. He often cites 'Kautsky-when-he-was-aMarxist' as an authority in order to convince his audience - even when this audience is made up of militant Bolsheviks for whom Kautsky was a bitter political foe. Lenin does not change his mind on this topic: the invocation of Kautsky as an authority is a constant feature of Lenin's pronouncements from 1914 to $1920 .^{1}$

\section{The ideas that underpinned Lenin's political platform after 1914 came directly from Kautsky and other orthodox writers.}

In previous writings, I have emphasized the negative conclusion that Lenin is not engaged in 'rethinking Marxism' or repudiating his own earlier admiration for Kautsky's writings. But Lenin's solidarity with Kautsky and other Marxist writers goes further. The ideas most important to Lenin after 1914 are also taken directly from Kautsky and others. In other words, Kautsky's prewar writings continue to be extremely influential for Lenin, and Lenin's political outlook in the years after 1914 cannot be understood apart from this fact.

The continuing influence of Second International orthodoxy should not be limited to Kautsky. True, Kautsky's role is vastly important and overshadows everybody else. Nevertheless, Lenin insists that he is building on an widespread orthodox consensus. Very often mentioned as an indicator of consensus is the Basel Manifesto of 1912 (as discussed below).

\footnotetext{
${ }^{1}$ See my remarks in the forthcoming symposium on Lenin's What Is to Be Done? in Historical Materialism and Lih 2008. I have compiled an extensive database of Lenin's post-1914 comments on Kautsky's pre-1914 writings, which can be obtained from me at larslih@yahoo.ca.
} 


\section{Lenin himself aggressively emphasized his own unoriginality and he had good rhetorical reasons to do so.}

Lenin himself informed all and sundry that his current definition of the situation was based solidly on the prewar consensus and on Kautsky's writings in particular. In October 1914, he wrote his lieutenant Aleksandr Shliapnikov: 'Obtain without fail and reread (or ask to have it translated for you) Road to Power by Kautsky [and see] what he writes there about the revolution of our time! And now, how he acts the toady and disavows all that!' (Lenin, 1958-64, 49:24). As we shall see, Lenin himself always remained loyal to Kautsky's vision of 'the revolution of our time'.

Lenin insists upon his own ideological indebtedness in an aggressive fashion not only to bring out the heinousness of the renegacy of Kautsky and others, but also to show that he, Lenin, is not just some solitary nut but rather an orthodox Marxist whose platform rests on the consensus of the most learned socialist writers. Of course, the fact that Lenin had rhetorical motivations for his stance of aggressive unoriginality is not a reason to doubt his sincerity and conviction. Lenin was not lying when he affirmed his solidarity with Kautsky - or, if he was, more proof is needed than merely his desire to persuade his audience.

Two comments before proceeding. First, when I speak of Lenin's 'unoriginality,' I do not mean to say that he slavishly took all his ideas from elsewhere. I make no assumption here about the actual source of Lenin's outlook or any particular part of it. What I do assert is that central aspects of Lenin's outlook are shared with Kautsky and others, and that Lenin himself insisted on this.

Second, today's admirers of Lenin want him to be original and picture him as seeing through the unrevolutionary Marxism of the Second International. Lenin's own self-image is very different. Lenin's subjective perception is important in itself, but, as it happens, Lenin's self-image is also an objectively accurate one. People who would like Lenin to be a profound 'rethinker' of Marxism may perceive my argument as an attack on him. This is not the case. If Lenin's ideas are good ones, they are good ones, regardless of whether or not he shared them with writers such as Kautsky. And conversely, if they are bad ones, the endorsement by socialist authorities does not make them any better.

As we have seen, in October 1914, Lenin advised his party comrade Shliapnikov to re-read Kautsky's 1909 book Road to Power. Lenin took his own advice, judging from an article published in December 1914 entitled 
Socialist Studies: the Journal of the Society for Socialist Studies 5(2) Fall 2009: 90-112

'Dead Chauvinism and Living Socialism' (Lenin 1960-68, 21:94-101). In this article he cited chapter and verse to demonstrate the excellence of Kautsky's analysis. I am going to cite the relevant passage in extenso, since it is (or, in any event, should be) central to any analysis of the historical context of Lenin's wartime platform. As scholarly 'value added', I have inserted page numbers to the specific passages quoted by Lenin (the references are to the English-language translation by Raymond Meyer). ${ }^{2}$

For decades, German Social-Democracy was a model to the Social-Democrats of Russia, even somewhat more than to the Social-Democrats of the whole world. It is therefore clear that there can be no intelligent, i.e., critical, attitude towards the now reigning social-patriotism or 'socialist' chauvinism, without a most precise definition of one's attitude towards German Social-Democracy, What was it in the past? What is it today? What will it be in the future?

A reply to the first of these questions may be found in Der Weg zur Macht [The Road to Power], a small book written by K. Kautsky in 1909 and translated into many European languages. Containing a most complete exposition of the tasks of our times, it was most advantageous to the German Social-Democrats (in the sense of the promise they held out), and moreover came from the pen of the most eminent writer of the Second International. We shall recall the pamphlet in some detail; this will be the more useful now since those forgotten ideals are so often barefacedly cast aside.

Social-Democracy is a 'revolutionary party' (as stated in the opening sentence of the pamphlet), not only in the sense that a steam engine is revolutionary, but 'also in another sense' [Road, 1]. It wants conquest of political power by the proletariat, the dictatorship of the proletariat. Heaping ridicule on 'doubters of the revolution,' Kautsky writes: 'In any important movement and uprising we must, of course, reckon with the possibility of defeat. Prior to the struggle, only a fool can consider himself quite certain of victory.' However, to refuse to consider the possibility of victory would be 'a direct betrayal of our cause' [Road, 11]. A revolution in connection with a war, he says, is possible both during and after a war. It is impossible to determine at which particular moment the sharpening of class antagonisms will lead to revolution, but, the author continues, 'I can quite definitely assert that a revolution that war brings in its wake, will break out either during or immediately after the war' [Road, 14]; nothing is more vulgar, we read further, than the theory of 'the peaceful growing into socialism' [Road, 21]. 'Nothing is more erroneous,' he continues, 'than the opinion that a cognition of economic necessity means a weakening of

\footnotetext{
${ }^{2}$ Kautsky 1996 (this edition has been recently re-issued). A contemporaneous English translation is available on the Marxists Internet Archive (www.marxists.org).
} 
the will... The will, as a desire for struggle,' he says, 'is determined, first, by the price of the struggle, secondly, by a sense of power, and thirdly, by actual power' [Road, 26-7].

When an attempt was made, incidentally by Vorwärts, to interpret Engels's famous preface to The Class Struggles in France in the meaning of opportunism, Engels became indignant, and called shameful any assumption that he was a 'peaceful worshipper of legality at any price' [Road, 33]. 'We have every reason to believe,' Kautsky goes on to say, 'that we are entering upon a period of struggle for state power.' That struggle may last for decades; that is something we do not know, but 'it will in all probability bring about, in the near future, a considerable strengthening of the proletariat, if not its dictatorship, in Western Europe' [Road, 42]. The revolutionary elements are growing, Kautsky declares: out of ten million voters in Germany in 1895, there were six million proletarians and three and a half million people interested in private property; in 1907 the latter grew by 0.03 million, and the former by 1.6 million! [Road, 49]. 'The rate of the advance becomes very rapid as soon as a time of revolutionary ferment comes' [Road, 51]. Class antagonisms are not blunted but, on the contrary, grow acute; prices rise, and imperialist rivalry and militarism are rampant [Road, 60-75].

'A new era of revolution' is drawing near [Road, 76]. The monstrous growth of taxes would 'long ago have led to war as the only alternative to revolution... had not that very alternative of revolution stood closer after a war than after a period of armed peace...' [Road, 80]. 'A world war is ominously imminent,' Kautsky continues, 'and war means also revolution' [Road, 84]. In 1891 Engels had reason to fear a premature revolution in Germany; since then, however, 'the situation has greatly changed.' The proletariat 'can no longer speak of a premature revolution' (Kautsky's italics) [Road, 84]. The petty bourgeoisie is downright unreliable and is ever more hostile to the proletariat, but in a time of crisis it is 'capable of coming over to our side in masses' [Road, p. 88]. The main thing is that Social-Democracy 'should remain unshakable, consistent, and irreconcilable' [Road, 89]. We have undoubtedly entered a revolutionary period [Road, 90].

This is how Kautsky wrote in times long, long past, fully five years ago. This is what German Social-Democracy was, or, more correctly, what it promised to be. This was the kind of Social-Democracy that could and had to be respected.

The page numbers I have inserted bring out Lenin's simple procedure: he sat down, went through the book page by page, and found something he liked on every few pages. In fact, Lenin's discussion, extensive as it is, underestimates the full overlap between Kautsky's analysis and his own post-1914 outlook. In the final chapters of Road to Power, Kautsky 
Socialist Studies: the Journal of the Society for Socialist Studies 5(2) Fall 2009: 90-112

sketches out a scenario of global revolution that he had been developing for a number of years-a scenario that Lenin accepted wholeheartedly and that became even more important to him as the years passed.

An analysis of all the issues contained in this passage would entail a full examination of Lenin's politics after 1914. In this essay I will comment on four major aspects of Lenin's aggressive unoriginality during this period.

\section{The General Idea of a Revolutionary Situation}

Both Kautsky and Lenin believed that there is such a thing as a 'revolutionary situation', one that has very different political dynamics from a peaceful situation and therefore requires a very different set of tactics. In Road to Power, Kautsky offered four conditions as necessary components of a revolutionary situation: a regime hostile to the people, a 'party of irreconcilable opposition, with organized masses,' mass support given to the party, and, finally, an acute crisis of confidence within the antipopular regime (Kautsky 1996, 45). Lenin later offered his own four-part definition of a revolutionary situation that, although it differs in details from Kautsky's, is obviously derived from it. Lenin comments, after giving his definition, 'such are the Marxist views on revolution, views that have been developed many, many times, have been accepted as indisputable by all Marxists, and, for us Russians, were corroborated in a particularly striking fashion by the experience of 1905.'3

One aspect of a revolutionary situation, as seen by both Lenin and Kautsky, is the idea that the political education of the masses accelerates tremendously. As Kautsky puts it in Road to Power:

When times of revolutionary ferment come, the tempo of progress all at once becomes rapid. It is quite incredible how swiftly the masses of the population learn in such times and achieve clarity about their class interests. Not only their courage and their desire to fight, but also their political interest is spurred on in the most powerful way by the consciousness that the moment has arrived for them to rise by their efforts out of the darkest night into the bright glory of the sun. Even the most sluggish become industrious; even the most cowardly, bold; even the most intellectually limited acquire a wider mental grasp. In such

\footnotetext{
${ }^{3}$ Compare Lenin 1960-68, 21:214 with Kautsky 1996, 45, 51 (Lenin's 1915 definition in Collapse of the Second International has three numbered parts, to which Lenin immediately adds a fourth, unnumbered condition).
} 
times, political education of the masses takes place in years, that otherwise would require generations (Kautsky 1996, 51).

Because of revolutionary situation is so distinct from a peacetime situation, it requires a fundamentally different set of tactics. This proposition underlies the famous distinction made by Kautsky in his 1910 polemics with Rosa Luxemburg: a 'strategy of attrition' vs. a 'strategy of overthrow.' Kautsky explained that the first tactic (the standard SPD activity of energetic socialist enlightenment and organization) was appropriate to a normal, non-revolutionary situation, whereas the second (mass political strikes and other non-parliamentary means of pressure) was appropriate to a genuinely revolutionary situation. Kautsky added that, while at present Germany was still in a non-revolutionary situation, nevertheless a revolutionary crisis could be expected very soon (Grunenberg 1970).

These points were taken up and emphasized in some very revealing polemics by Bolshevik writers in 1910-1911. I shall discuss Kautsky's concrete prediction of an imminent revolutionary crisis in the next section. Here I shall look at how Bolshevik writers endorsed Kautsky's contrast between tactics appropriate to a revolutionary situation vs. those appropriate to a non-revolutionary situation.

Both Kautsky and Luxemburg were supporters of the general Bolshevik strategy of relying on peasant rather than liberal allies in the upcoming democratic anti-tsarist revolution. Menshevik writers were therefore glad to see the sharp dispute between Kautsky and Luxemburg and were quick to claim that Kautsky was finally moving away from his quasi-Bolshevism. Iulii Martov made this argument in an article published in Kautsky's own journal, Die Neue Zeit. Martov regretted that during the revolutionary year 1905, after the tsar had granted basic political freedoms in October, 'the idea of the possibility of a "strategy of attrition" entered nobody's head.' Instead, the workers embarked on the doomed uprising of December 1905 and met a bloody defeat. But today (Martov continued), in 1910, even hardened Bolsheviks like N. Lenin admitted that 'up to now we "spoke French", but now the time has come to "speak German"' - that is, switch from the impatient revolutionary methods of the French to the patient, long-term methods of the Germans.

Martov glossed Lenin's metaphors: not 'speak French,' but speak 'Blanquist' (that is, conspiratorial putschism). Not 'speak German,' but speak 'the universal [allgemeinmenschliche] method of Socialist work' 
Socialist Studies: the Journal of the Society for Socialist Studies 5(2) Fall 2009: 90-112

(Martov 1910, 910-13). ${ }^{4}$ Thus Martov and other Menshevik writers maximized the clash between Kautsky and Luxemburg. They pictured Kautsky as rejecting the Blanquist 'strategy of overthrow' in favor of the universally applicable 'strategy of attrition.'

Martov's reading of Kautsky was directly challenged in Die Neue Zeit by Julian Marchlewski, a Polish Social Democrat associated with the Bolsheviks. Marchlewski pointed out that Kautsky himself used Russia in 1905 as a situation in which the 'tactic of overthrow' was appropriate. Therefore, 'Martov has messed up [verballhornt] Kautsky's train of thought - he [Martov] wants the "strategy of attrition" to be applied always and under all circumstances. This is opportunism pure and undefiled. And it is truly a hair-raising misunderstanding for him to call on Kautsky for support' (Marchlewski 1910,101). This particular 'hair-raising misunderstanding' of Kautsky is still widespread today.

Marchlewski went back to Lenin's actual comment (made in summer 1909) about 'speaking French' vs. 'speaking German' and showed that Martov had distorted Lenin's point. Martov incorrectly implied that Lenin was conceding that 'speaking French' had been a mistake. Lenin's actual point was that basic strategy had to correspond to the nature of the existing situation. In Lenin's words:

During the revolution we learned to 'speak French,' that is, to introduce into the movement the greatest number of rousing slogans, to raise the energy of the direct struggle of the masses and extend its scope. Now, in this time of stagnation, reaction and disintegration, we must learn to 'speak German,' that is, to work slowly (there is nothing for it, until things revive), systematically, steadily advancing step by step, winning inch by inch. ${ }^{5}$

On the basis of this passage, Marchlewski draws a highly significant conclusion about Lenin, Kautsky, and the concept of a revolutionary situation: 'As you can see, Lenin says here in concise words that tactics must be applied in an exact way to the situation; he recommends, if you will, the same thing as did Kautsky [a year later]: application of the "strategy of overthrow" and the "strategy of attrition" at the correct time' (Marchlewski 1910, 102). ${ }^{6}$

\footnotetext{
${ }^{4}$ Although in quotes, Martov's words are a paraphrase of Lenin's argument. Martov also attacked Rosa Luxemburg for urging the SPD to 'speak Russian,' that is, to abandon its own correct tactic in favor of a tactic renounced in Russia itself even by extremists such as Lenin.

${ }^{5}$ July 1909 (see Lenin 1960-68, 15:458; Lenin 1958-64, 19:50).

${ }^{6}$ Lenin explicitly endorsed Marchlewski's critique of Martov (NB: Marchlewski wrote under the name of J. Karski).
} 


\section{The Looming Revolutionary Situation and the Role of War}

Starting at least as early as 1902, in his book Social Revolution, Kautsky had insisted that class antagonisms were sharpening - not softening, as argued by revisionists - and that a revolutionary crisis was brewing, both in Europe and on a global scale. In his 1909 book Road to Power, he tied the onset of a revolutionary situation to the increasingly probable outbreak of war. In his 1910 dispute with Luxemburg, he tied the onset of crisis even more tightly and explicitly to current political developments in Prussia.

For Lenin, writing in 1910, Kautsky's prediction of an imminent political crisis was a crucial and overlooked aspect of the KautskyLuxemburg dispute. Lenin pointed out that 'Kautsky said clearly and directly that the transition [to a strategy of overthrow] is inevitable during the further development of the political crisis' (Lenin 1958-64, 19:367). Lenin therefore minimized the significance of the clash between the German party's two honorary Bolsheviks: they both believed that a fundamental turning point comparable to Bloody Sunday in January 1905 was in the works. The only disagreement was whether this turning-point would occur 'now or not just yet, this minute or the next minute' (Lenin 1958-64, 20:18).

In a 1912 article, Lev Kamenev-one of Lenin's closest lieutenants at this time-also stressed Kautsky's prediction of a looming revolutionary crisis. In an effort to further minimize the significance of the clash, he added:

It is possible, even while agreeing with Kautsky in his analysis of existing objective conditions, to see at the same time that the propaganda and agitation of his opponents on the left, and their critique of the insufficient initiative of the leading elements of the party-that these things not only reflect the growing mood of the masses, but also that they are a necessary element of the preparation of the masses for the coming 'great battles' (Kamenev 2003, 670).

Accordingly, Kamenev divided the SPD left-wing into two tendencies: 'the advocates of a more active, mass-oriented tactic that reflects the mood of the lower classes [nizy]' vs. 'the careful leaders of the party, defending the old ways and not wanting to leave them until a switching over to new rails was dictated by the class enemy of the proletariat'. When this article was reprinted in 1922, Kamenev appended the following comment to the passage just quoted: 'Alas, they did not want to leave these old ways even when the class enemy issued a direct challenge to the proletariat. We thought better of them than they deserved' (Kamenev 2003, 671). 
Socialist Studies: the Journal of the Society for Socialist Studies 5(2) Fall 2009: 90-112

Thus, even in 1922, Kamenev does not say that Kautsky was wrong and Luxemburg was right in their 1910 debate. Kautsky was right about the objective situation: the 'strategy of overthrow' was not applicable in 1910. Kautsky was also right about the impending revolutionary situation. But with hindsight, the Bolsheviks could see that Luxemburg was right about Kautsky - that is, her suspicion that Kautsky would never switch rails was well-founded.

Looking back in 1917, Lenin used Kautsky's idea of two strategies and used it to critique Kautsky's own inability to switch from 'speaking German' to 'speaking French.' In this respect, Kautsky was a representative of a whole stratum of people addicted to routine and to conditions of legality:

Speaking historically and economically, [these people] do not represent a special stratum, they represent only a transition from an outlived phase of the worker movement, from the phase of 1871-1914 - a phase that gave much that was valuable, especially in the art, so necessary for the proletariat, of slow, consistent, systematic, organized work in broad, very broad, fashion - to a phase that is new, one that became objectively necessary from the time of the imperialist war, opening an era of social revolution (Lenin 1958-64, 31:171-2).

In Lenin's view, the outbreak of war created a revolutionary situation almost by definition-and once again, Kautsky is a primary authority. Writing in early 1916, Lenin is outraged that Kautsky is now denying the need for revolutionary action, especially since 'the one denying revolutionary action is the very same authority of the Second International who in 1909 wrote a whole book, Road to Power, translated into practically all the major European languages and demonstrating the link between the future war and revolution' (Lenin 1958-64, 27:109-10).

In late 1918, in his masterpiece of aggressive unoriginality Proletarian Revolution and the Renegade Kautsky, Lenin claimed that the link between war and revolution was a commonplace among all prewar Marxists:

Long before the war, all Marxists, all socialists were agreed that a European war would create a revolutionary situation... So, the expectation of a revolutionary situation in Europe was not an infatuation of the Bolsheviks, but the general opinion of all Marxists (Lenin 1960-68, 28:289, 292).

Besides Kautsky's writings, Lenin's major piece of evidence for this assertion was the Basel Manifesto of 1912. This manifesto was issued by an emergency conference convened by the Second International in Basel, Switzerland in November 1912, for the purpose of protesting against the 
growing likelihood of war. In an impressive show of unity, the conference unanimously passed a manifesto that committed the socialist parties to use the outbreak of war to advance revolution. 'Let the governments remember that, given the present condition of Europe and the mood of the working class, they cannot unleash a war without danger to themselves' (Riddell 1984, 89).

According to Lenin, the official socialist parties failed to act on the solemn commitment they had made at the Basel conference. In so doing, they betrayed the whole history of the Second International, for the Basel Manifesto was nothing more than a summary of

millions and millions of proclamations, newspaper articles, books, speeches of the socialists of all countries [from] the entire epoch of the Second International, 1889-1914... To brush aside the Basel Manifesto means to brush aside the whole history of socialism. The Basel Manifesto does not say anything special, anything extraordinary. It provides only and exclusively that by means of which the socialists gained the following of the masses: the acknowledgement of 'peaceful' work as a preparation for the proletarian revolution (Lenin 1958-64, 27:102).

In other words, Lenin and his fellow-thinkers represent continuity with the outlook of the Second International. The leaders of the official socialist parties are the ones who are 'brushing aside the whole history of socialism.'

\section{The Continuity of 'Opportunism'}

'Opportunism' had always been the great enemy of what Lenin and others called 'revolutionary Social Democracy.' The opportunists were sincere and committed socialists, but unlike the orthodox Marxists, they believed more in class collaboration than class conflict as a way to achieve socialism. The lesson Lenin drew from the support given to the war by the official parties was not the existence of a strong opportunist wing in the Second International. He knew that already. What surprised and shocked him was the revelation of just how powerful opportunism had become.

His full explanation of the collapse of the Second International goes something like this: All during the history of the Second International, there has been a fight between revolutionary Social Democracy and opportunism. All prominent Marxists had realized that opportunism was a strong and growing internal threat to the integrity of Social Democratic parties. Kautsky in particular was one of the foremost fighters against opportunism, and his analysis remains useful today. But very few realized 
just how far the rot had gone until the crisis of 1914 revealed it. The 'social chauvinism' and 'social patriotism' now current is merely the present-day expression of this age-old opportunism. Opportunism was a malignant cancer that has destroyed the official parties of the Second International, but its triumph will not be long-lived. The immediate task of those who remain loyal to revolutionary Social Democracy is to found a new, opportunism-free international.

Thus Lenin. Even when Lenin has condemned the old international root and branch, even when he insists on the necessity of creating a new international, he is explicitly operating with the traditional concept of opportunism. As he remarked in 1915, 'hardly a single Marxist of note can be found who has not acknowledged many times and on a variety of occasions that the opportunists are truly hostile to the socialist revolution, a non-proletarian element' (Lenin 1958-64, 26:113). ${ }^{7}$ In the spirit of aggressive unoriginality, he is happy to give Kautsky his due credit in fighting opportunism in the past. Even the project of splitting Social Democracy if opportunism becomes too powerful is buttressed by Kautsky's authority. ${ }^{8}$

The political thinking behind this wager on anti-opportunism is expressed in the following passage from Kautsky's Road to Power, one that Lenin directly cites in his article of December 1914 discussed earlier:

The more the Social Democratic Party maintains itself as an imperturbable power in the midst of the perturbations of authority of every kind, all the higher will its authority rise. And the more it persists in irreconcilable opposition to the corruption of the ruling classes, all the greater will be the trust placed in it by the great masses of the people in the midst of the general decay that today has laid hold even of the bourgeois democrats, who are completely abandoning their principles in order to win the government's favor.

\footnotetext{
${ }^{7}$ Many of the ideas put forth by Lenin and his associates about the social roots of opportunism - for example, a 'labour aristocracy' bribed by gains from imperialism - were also widely bruited before the war. For further documentation of Bolshevik aggressive unoriginality on the nature of imperialism, see Riddell 1984, 82-3 and 461-2.

${ }^{8}$ 'This same Kautsky wrote 15 years ago, at the beginning of the Bernstein affair, that if opportunism changed from a mood to a tendency, a split would be on the order of the day' (from 'Dead Chauvinism and Living Socialism', Lenin 1958-64, 26:102). Lenin also credits Kautsky with the idea of changing the party's name from Social Democracy to Communist (Lenin 1958-64, 26:95 [December 1914]). Other Lenin comments on Kautsky and opportunism are quoted below.
} 
The more imperturbable, consistent, and irreconcilable the Social Democratic Party remains, all the more readily will it get the better of its opponents.

To demand that the Social Democratic Party participate in a policy of coalition or alliance now, when the dictum about the 'reactionary mass' has become reality, is to expect the Party to commit political suicide. To want the Social Democratic Party to link itself with bourgeois parties through an alliance policy now, at the very time when those parties have prostituted and utterly compromised themselves; to want the Party to link itself with them in order to further that very prostitution-is to demand that it commit moral suicide (Kautsky 1996, 89-90; the italicized words are those directly cited by Lenin).

In this Kautsky passage from 1909, we see foreshadowed - no, not foreshadowed, but described in detail - Lenin's political strategy in 1917. To compromise with 'opportunism', to cooperate with bourgeois parties, is to commit moral and political suicide. To stand forth proudly as an uncompromising party of irreconcilable opposition to the existing system is the path to receiving mass support.

\section{Fighting Doctrinal Innovation}

Lenin indulged in his usual share of doctrinal polemics in the period 19141916. People often think of Lenin as breaking new ground in these polemics. What Lenin himself says he is doing, however, is defending established doctrine against newfangled distortions. I believe his selfimage as a defender of orthodoxy is an accurate one. Three issues stand out among the polemics of this period. I list them in the order of the appearance of the innovations, not the order in which Lenin responded to them in print.

\section{2: Kautsky on the state}

The polemic against the Second International in Lenin's State and Revolution (1917) fall under two categories: forgetting or overlooking vital Marxist points about the state and actively distorting Marxist theory. The accusation of forgetting applies mainly to the actions of the official socialist parties after the outbreak of war and thus is a typical example of aggressive unoriginality.

Lenin provides exactly one example of theoretical distortion, namely, an article Kautsky wrote in 1912 in a polemic with Anton Pannekoek (Kautsky 1912). A full analysis of Lenin's critique would be out of place in this essay. A couple of points need to be made. First, this post- 
Socialist Studies: the Journal of the Society for Socialist Studies 5(2) Fall 2009: 90-112

1909 Kautsky article is much more crucial to Lenin's critique than anything written by Kautsky before 1909 - so much is clear from the text of State and Revolution itself as well as from Lenin's various mentions of his book elsewhere. ${ }^{9}$

Further, and most importantly, Lenin is not critiquing Kautsky's orthodoxy from the point of view of some new, more radical understanding of Marx. On the contrary, he is affirming standard prewar Marxist orthodoxy and claiming (on dubious textual grounds) that Kautsky's 1912 article rejects this orthodoxy. According to Lenin, Kautsky argues or implies in his 1912 article that officials (whether of party or state) will never be subject to genuine democratic control, that officials will always be 'bureaucrats, that is, privileged persons detached from the masses and standing above the masses,' that existing bourgeois parliamentary institutions do not need to be democratically transformed, that a socialist revolution will achieve no more than 'a government willing to meet the proletariat halfway,' and that fully democratized proletarian class rule is not a necessary 'foundation for the socialist reconstruction of society' (Lenin 1960-68, 25:483-91). If Kautsky did indeed believe any of these things, then we can say that he had indeed become an out-and-out opportunist who rejected what he himself had written many times earlier.

Lenin's picture of the long-term 'dying away of the state' is also in line with prewar orthodoxy. 'Under socialism, everybody will administer in turn, and will quickly become accustomed to the idea that no one administers' (Lenin 1960-68, 25:488). The idea behind Lenin's wellknown epigram was almost a cliché among prewar Marxists and even among non-socialist democrats (Lih 2006). Modern-day readers of State and Revolution, unfamiliar with the real outlook of the Second International on these matters, are likely to misinterpret the thrust of Lenin's polemic. For Lenin, Kautsky's 1912 article was the smoking gun that proved that Kautsky had abandoned certain key tenets of his earlier 'revolutionary Social Democracy' and now openly sided with the opportunists on this question.

\footnotetext{
${ }^{9}$ For documentation, see note 1 . Lenin was scandalized by Kautsky's article as soon as it appeared. In a 1912 letter to Kamenev, Lenin called it 'arch-opportunist' and demanded a 'principled rebuff' to Kautsky (Lenin 1958-64, 48:87). In other words, Lenin's dislike of this article was not caused by any re-evaluation of Kautsky after the 1914 'betrayal'.
} 


\section{4-1915: Kautsky on 'Ultra-Imperialism'}

The historical context of Lenin's polemics with Kautsky about imperialism is set forth very clearly in The Socialists and the War by William English Walling. This encyclopedic book by an American socialist was published in May 1915 and represents an invaluable contemporaneous survey of disputes within the international socialist movement.

Walling introduces Kautsky as follows: 'While [Kautsky] represents the orthodox Marxian view, he does not pretend to leave the Marxian doctrine intact on war or on any other matter. Indeed, he has done more than any other living writer to develop that standpoint, and this is why, no doubt, he is known as the world's leading Marxian.' Walling then points out that in his latest articles on imperialism, Kautsky is breaking new ground: 'Kautsky here renounces the widely prevalent Socialist belief (often seen in the following documents) that capitalism necessarily means war, or that permanent peace must wait for Socialism. He takes the contrary view' (Walling 1915, 16-8).

As a typical expression of the standard Marxist view, Walling gives excerpts from articles by a prominent American socialist, Morris Hillquit. In articles published in 1914-1915, Hillquit makes the following assertions:

The Socialists [as opposed to bourgeois pacifists] realize that under existing conditions wars are inevitable. The Socialists assert that wars are bound to become more frequent and violent as the capitalist system approaches its climax ... The clash might have come somewhat earlier. It might have been delayed somewhat. But in the long run it was inevitable. It is idle to place the blame for the monstrous crime on any particular nation or government, to seek the aggressor. Capitalism has made this war, and all the nations are the victims. ${ }^{10}$

Walling comments that if we wish to know what the Socialist thought on war was becoming immediately before the present struggle, we must look to Kautsky and [Otto] Bauer. If we wish to know what it actually was, we must look to Hillquit' (Walling 1915, 21).

Lenin remained loyal to socialist thought as 'it actually was' and resisted Kautsky's innovative speculation about the possibility of 'ultraimperialism'. Kautsky now argued:

From the purely economic standpoint, it is therefore not excluded that capitalism may yet experience a new phase, namely the transposition of the

${ }^{10}$ These excerpts from Hillquit are from articles published in 1914-1915 (Hillquit's emphasis); they can be found in Walling 1915, 22-3. 
Socialist Studies: the Journal of the Society for Socialist Studies 5(2) Fall 2009: 90-112

policy of the cartels to the realm of foreign policy-in other words, a phase of ultra-imperialism, which naturally we would have to combat as energetically as we combated imperialism, but the danger of which would take a different form, not a world arms race and threat to world peace (Salvadori 1979, 189).

Lenin's hostility to Kautsky's new ideas about ultra-imperialism meant that his 1916 book, Imperialism, became an exercise in defending Kautsky-then against Kautsky-now. As he explained in a preface to this work written in 1920, 'Special attention has been devoted in this pamphlet to a criticism of the international ideological trend of kautskianstvo... The views held by Kautsky and his like are a complete renunciation of the very same revolutionary principles of Marxism which he championed for decades, especially in his struggle against socialist opportunism (Bernstein, Millerand, Hyndman, Gompers, etc.)' (Lenin 1960-68, 22:192). ${ }^{11}$

\section{6: Right of National Self-Determination}

In 1916, Lenin was involved in two major disputes over the national question, particularly over the right of self-determination and of secession. In each case, he pictured himself as fending off attacks on the official recognition of the right of national self-determination by the Russian Social Democratic Party, as stated in its program of 1903. In each dispute, he reaffirmed his solidarity with Kautsky's prewar writings and used him as an authority to rebut his opponents.

In 1903, at the Second Party Congress, the main opponents of Point Nine of the party's 'minimum program' - the recognition of the right of national determination - were Polish socialists who rejected the idea of separation from Russia as reactionary bourgeois nationalism. In 19131914 , the same dispute arose once again and Lenin waded in with a polemic aimed particularly at Rosa Luxemburg. Lenin repeated his basic point that

if we do not put forth and emphasize in our agitation the slogan of the right to separation, we play in the hands not only of the bourgeoisie of oppressing nations, but also of its feudalists and its absolutism. Kautsky put forth this

\footnotetext{
${ }^{11}$ The Second International Marxist quoted most extensively and favorably in Lenin's Imperialism is Rudolf Hilferding, the Austrian author of Finance Capital (Hilferding 1910). In the wartime writings of Lev Kamenev and Nikolai Bukharin, Hilferding is also praised for his 'brilliantly' prophetic analysis (Kamenev 1922). For Bukharin's use of Hilferding to refute Kautsky's theory of 'ultra-imperialism,' see Bukharin 1915, 86-8, 92-3.
} 
conclusion against Rosa Luxemburg a long time ago, and it cannot be disputed (Lenin 1958, 25:275). ${ }^{12}$

These words were written in 1914, before the beginning of the war and Lenin's break with Kautsky. In 1916, when preparing his 1914 article for republication, Lenin was aware that his invocation of Kautsky as an authority might lead to misunderstanding. He therefore commented in a footnote: 'We ask the reader not to forget that Kautsky up to 1909, up to his excellent book Road to Power, was a foe of opportunism, to whose defense he turned only in 1910-11, and completely decisively only in 191416' (Lenin 1958-64, 25:259).

In 1916, a group of Polish socialists returned to the attack. Their manifesto, drafted by Karl Radek, emphasized their discontinuity with the prewar Second International: 'The self-determination formula was left to us as an inheritance from the Second International... The policy of defense of the fatherland has brought results in the World War that very clearly show the counterrevolutionary nature of the self-determination formula' (Riddell 1984, 350-1).

In response, Lenin emphasized continuity with prewar polemics. He argued that the critics of Clause Nine in 1916 were making exactly the same mistake made by the critics back in 1903. In each case, the 'theoretical kernel' of the debate was that a dismissive attitude to the right of national self-determination was a form of 'economism,' a Russian form of opportunism that downgraded the urgency of democratic revolution (Lenin 1960-68, 22:326). ${ }^{13}$

In fall 1916, Lenin was forced to respond to yet another attack on Clause Nine, this time from left-wing Bolsheviks such as Nikolai Bukharin and Iu. Piatakov. Again recalling the 1903 debates, Lenin called Piatakov's position 'imperialist economism.' Once again, Kautsky was used to buttress Lenin's contention that a democratic war for national selfdetermination was still possible in the imperialist age:

\footnotetext{
${ }^{12}$ Lenin refers to Kautsky articles from 1895 and 1908.

13 Later in this article on national self-determination, Lenin refers to 'the resolution of our Party in 1913 giving a precise 'antikautskianskoe' definition (that is, one that does not tolerate purely verbal 'recognition') of the content of the issue' (Lenin 1958-64, 22:358). This comment dramatically underscores the gulf between kautskianstvo (revolutionary words without revolutionary deeds) and Kautsky's ideas, since, as we have seen, the 1913 resolution was defended by Lenin precisely by invoking Kautsky's pronouncements on national selfdetermination.
} 
Socialist Studies: the Journal of the Society for Socialist Studies 5(2) Fall 2009: 90-112

Up to the 1914-1916 war, Karl Kautsky was a Marxist, and many of his major writings and statements will always remain models of Marxism. On August 26, 1910, he wrote in Die Neue Zeit, in reference to the imminent war: 'In war between Germany and England the issue is not democracy, but world domination, that is, exploitation of the world. That is not an issue on which Social-Democrats can side with the exploiters of their nation.'

There you have an excellent Marxist formulation, one that fully coincides with our own and fully exposes the present-day Kautsky, who has turned from Marxism to defense of social-chauvinism. It is a formulation (we shall have occasion to revert to it in other articles) that clearly brings out the principles underlying the Marxist attitude towards war. War is the continuation of politics. Hence, once there is a struggle for democracy, a war for democracy is possible. National self-determination is but one of the democratic demands and does not, in principle, differ from other democratic demands (Lenin 1960$68,23: 35)$.

We have finished our brief survey of Lenin's aggressive unoriginality in the years 1914-1916. Lenin vehemently claims that his own definition of the current situation is based solidly on the prewar consensus of revolutionary Marxists, especially as expressed in the writings of Karl Kautsky. The key themes in his political platform - the underlying idea of a revolutionary situation, the assertion that the world war had create a revolutionary situation, the obligations of the socialist parties to oppose the war and to work for revolution, the causes and consequences of their failure to meet these obligations-are all firmly anchored by him in this prewar consensus. Attempts by Kautsky and others to move away from the consensus are met by Lenin with a firm rebuttal.

Somewhat different expressions of aggressive unoriginality characterize both the revolutionary year 1917 and the first year and a half of power. At the end of 1918, in his book-length polemic against 'renegade Kautsky,' Lenin uses this kind of rhetoric to describe his differences with Kautsky on the issues of bourgeois vs. proletarian democracy, international revolution, and peasant policy. During 1919, Lenin began to realize that certain key Bolshevik assumptions were not panning out. Among these were assumptions about international revolution, peasant policy, economic 'steps toward socialism,' and proletarian democracy. Of course, Lenin does not reject his earlier outlook. Indeed, he makes as little cognitive adjustment as possible. Nevertheless, he ruefully realizes that day-to-day policy can no longer be premised on the expectation of immediate 
revolution in Europe, of steady 'steps toward socialism,' and the like. This period of Lenin's activity might be called 'reluctant originality.'14

We will conclude by addressing the following paradox. How is it that Lenin, standing almost alone and taking on the entire socialist establishment, emphasized his own unoriginality? The answer to this natural query is that Lenin saw his task as the one shamefully forfeited by socialists such as Kautsky, namely, devising the new tactics called for by the long-predicted revolutionary situation.

It is the $A B C$ of Marxism that the tactics of the socialist proletariat cannot be the same both when there is a revolutionary situation and when there is no revolutionary situation... When Kautsky was still a Marxist, for example, in 1909, when he wrote his Road to Power, it was the idea that war would inevitably lead to revolution that he advocated, and he spoke of the approach of an era of revolutions... But in 1918, when revolutions did begin in connection the war, Kautsky, instead of explaining that they were inevitable, instead of pondering over and thinking out the revolutionary tactics and the way and means of preparing for revolution, began to describe the reformist tactics of the Mensheviks as internationalism. Isn't this apostasy? (Lenin 1960-68, 28:289, 283).

This was Lenin's self-appointed task: 'pondering over and thinking out the revolutionary tactics and the way and means of preparing for revolution' in the new yet long-predicted revolutionary situation- not just for Russia, but for Europe as a whole. He had the strength of will (or foolhardiness, or conceit?) to move beyond his previous focus on Russia and assert a claim to European leadership because he felt that the leaders who should have worked out these new tactics had failed to do so. He had the courage to take on the entire socialist establishment precisely because he felt that he, and not they, represented the prewar consensus of Marxist socialism.

\section{Acknowledgements}

This essay is based on a talk given at the annual meetings of the Society for Socialist Studies, May 2009, in Ottawa. My thanks are due to the anonymous referees for their valuable suggestions.

\footnotetext{
${ }^{14}$ Lenin's adjustments during this period will be described in more detail in my forthcoming biography of Lenin from Reaktion Books.
} 


\section{References}

Bukharin, Nikolai. 1915. Mirovoe khoziaistvo i imperialism. In N. I. Bukharin, Problemy teorii i praktiki sotsializma: 21-93. Moscow: Gosizdat.

Grunenberg, Antonia (ed.). 1970. Die Massenstreikdebatte. Frankfurt: Europäische Verlagsanstalt.

Hilferding, Rudolf. 1910. Das Finanzkapital: eine Studie über die jüngste Entwicklung des Kapitalismus. Vienna: I. Brand.

Kamenev, Lev. 1922. Ekonomicheskaia sistema imperializma i zadachi sotsializma, $3^{\text {rd }}$ ed. Moscow: Gosizdat.

Kamenev, Lev. 2003. Mezhdu dvumia revoliutsiiami. Moscow, Tsentrpoligraf.

Kautsky, Karl. 1912. 'Die neue Taktik.' Die Neue Zeit, 30 (II): 654-64.

Kautsky, Karl. 1996 (1909). The Road to Power: Political Reflections on Growing into the Revolution (translated by Raymond Meyer, ed. John Kautsky). New Jersey: Humanities Press.

Lenin, V. I. 1958-1964. Polnoe sobranie sochinenii, $5^{\text {th }}$ ed. Moscow, Gosizdat.

Lenin, V. I. 1960-1968. Collected Works. New York: Foreign Languages Press.

Lih, Lars T. 2006. Review of Marc Angenot, Jules Guesde, ou: Le Marxisme orthodoxe. Kritika 7, no. 4: 905-18

Lih, Lars T. 2008. 'Lenin and Kautsky: The Final Chapter.' International Socialist Review 59. Available online at http://www.isreview.org/issues/59/feat-lenin.shtml.

Marchlewski, Julian (J. Karski). 1910. 'Ein Missverständnis.' Die Neue Zeit, 29 (I): 100107.

Martov, L. 1910. 'Die preussische Diskussion und die russische Erfahrung.' Die Neue Zeit, 29, II: 907-919.

Riddell, John (ed.). 1984. Lenin's Struggle for a Revolutionary International. New York: Monad Press.

Salvadori, Massimo. 1979. Karl Kautsky and the Socialist Revolution 1880-1938. London: Verso.

Walling, William English. 1915. Socialists and the War. New York: H. Holt and Co. 